\title{
SWOT Analysis of Eco-Labels and their Projection on Sustainability Spectrum: A Theoretical Evaluation of Destination India
}

Shamima Akhter ${ }^{*}$ and M A Darzi ${ }^{\dagger}$

\section{Abstract}

Most of the organisations in India follow contemporary practices of sustainable development but very few have obtained 'green' certifications, and tourism industry is no exception. A booming economy, with a population of over 1.2 billion, India's infrastructure constructions are soaring, resulting in a depletion of rare flora and fauna species and an increase in pollution of water bodies. Against the backdrop of these three constituents, this paper presents a SWOT analysis of three important ecolabels which covers almost all sectors of the tourism industry. Further, an evaluation of this ecolabel implementation in India is done through sustainability spectrum vis-a-vis sustainability positions.

Keywords: Ecolabels, SWOT analysis, Blue flag, Green globe, PAN parks, Sustainability.

\section{Introduction}

With the onset of reforms to liberalize Indian economy in the early 1990s, our globalized nation became a haven for gaining voracious financial benefits for all businesses. A sense of economic gains at any cost, became a norm and ultimately, the main focus of every

\footnotetext{
Research Scholar, IGNOU, New Delhi, India; shamimaakhter2@gmail.com

t Associate Professor, Kashmir University, Kashmir, India; mushtaqad62@yahoo.co.in
} 
organisation and the stakeholders involved. However, over the past decade some conscious members of the population have become increasingly interested in learning more about the way in which these businesses may affect the environment. This article is one such endeavour in providing awareness about 'Green consumerism' through the concept of 'ecolabelling'. Though new to Indian tourism scenario, the SWOT analysis of ecolabels in this paper gives an expeditious overview of three renowned international ecolabels which are directly related to tourism industry which is: Blue Flag, Green Globe and PAN Parks. Each ecolabel is analysed individually in the Indian context wherein both its counterparts and competitors are discussed in the wake of sustainable tourism development and its promotion. Furthermore, a matrix is developed to project these ecolabels on 'Destination India' using two frameworks related to sustainability. The first framework called the sustainable development spectrum designates sustainability positions to each ecolabel in the grid. The second framework called the prism of sustainability has four dimensions viz- Institutional, Social, Economic and Environmental. All the four dimensions of all three ecolabels are separately analysed in a descriptive form. To reduce the complexity of the matrix, both frameworks are used simultaneously to provide a simplified presentation and understanding to the reader with detailed findings and conclusive suggestions towards the end.

\section{Objectives}

- To gain an insight about ecolabels and acquire detailed knowledge about three international ecolabels important to tourism industry.

- To examine methodically the strengths, weaknesses, opportunities and threats of the ecolabels blue flag, green globe and PAN parks.

- To look at Indian perspective of sustainable tourism development vis-a-vis Indian tourism industry ecolabelling.

- To evaluate Indian ecolabelling implementation and its projection on sustainability spectrum. 
- To analyse sustainable tourism development in India on four dimensions viz- economic, social, institutional and environmental, and their implications for sustainability positions.

\section{Methodology}

This study is analytic in nature and hence discusses the theoretical aspects of all the concepts mentioned in the work. The methodology applied takes into account the surveying of both published and unpublished literature; using information sources of the websites relevant to the themes and secondary data from journals, books, magazines and newspapers. Based on available information, an evaluation of the Indian ecolabelling system was done by applying two sustainability frameworks against three green certifications to reach a conclusion via detailed findings.

\section{Ecolabels: An Overview}

'Ecolabelling' is a voluntary method of environmental performance certification and labelling that is practised around the world. An 'ecolabel' is a label which identifies overall, proven environmental preference of a product or service within a specific product/service category (Global Ecolabelling Network, n.d).

These labels are a form of sustainability measurement and are designated to products by manufacturers to indicate to customers that the products meet certain standards. These standards can be developed by private entities, by public agencies under their authorities, or jointly by stakeholders and experts from the public and private sectors (Introduction to Ecolabels and Standards, n.d). In other words, these labels are awarded by an impartial third party in relation to certain products or services that are independently determined to meet transparent environmental leadership criteria. There are around 436 ecolabels, in 197 countries and 25 industry sectors (Ecolabel Index, n.d)

Raising awareness and creating trust among customers, the first ecolabel appeared 33 years ago. The base of ecolabelling can be established in the progressive world distress for environmental protection on the part of governments, businesses and the public 
(Global Ecolabelling Network, n.d). Stakeholders have realized that environmental concerns can be translated into a market advantage for certain products and services, therefore, various environmental declarations/claims/labels have emerged on products and services in the marketplace (e.g. natural, recyclable, eco-friendly, low energy, recycled content, etc.). Certainly, many eco-labels have done a great deal to combat adverse environmental effects, to change what we expect from certain product categories and to build capacity and create a common framework around sustainability. Ultimately, eco-labels strive to accelerate sustainable behaviour. Neither consumers nor producers can be expected to do the right thing unless they know what that is, and eco-labels are to be commended for focusing on this need - as are the global companies who are pushing to make effective use of them (Aldred, 2009).

Now let us look briefly at the three main eco-labels which are directly related to the tourism industry and their contribution in general:

\section{Blue Flag}

The Blue Flag is a voluntary eco-label awarded to beaches and marinas across the world. Compliance with the Blue Flag criteria requires adherence to water quality standards, safety, the provision of services and general environmental management (Blue Flag Beach, n.d). The label, so far, has been awarded to over 3200 beaches and marinas in 37 countries across Europe, South Africa, Morocco, Tunisia, New Zealand, Canada and the Caribbean. Furthermore, the programme is owned and run by the independent non-profit organization Foundation for Environmental Education (FEE).

Born in France in 1985 where the first French coastal municipalities were awarded this status, the Blue Flag at the European level started in 1987 (Blue Flag, n.d.). The Foundation for Environmental Education in Europe (FEEE) presented the concept of the Blue Flag to the European Commission, in which it was agreed to launch the programme in entire Europe. In 2001, FEE decided to become a global organization by changing the name from FEEE to FEE (Foundation for Environmental Education). 


\section{Key Highlights}

In order to get Blue Flag certified, all the following information must be displayed on the location: bathing water quality, coastal zone ecosystems, natural and sensitive areas in the coastal zone, Blue Flag Programme and code of conduct for the beach area plus a minimum of five environmental education activities must be offered by the beach authorities.

In addition to that, compliance with the requirements and standards for excellent bathing water quality and no discharge of industrial or sewage is compulsory because it affects the beach area directly and indirectly. Regular monitoring of the health of coral reefs and other vegetation located in the vicinity of the beach has to be done strictly. A beach management committee is established which is in charge of instituting environmental management systems and conducts regular environmental audits of the beach facilities like ensuring adequate and clean sanitary facilities with controlled sewage disposal, receiving recyclable waste materials etc. A separate management committee for provision of safety and services is also established like those for emergency purposes, overall safety of the beach etc.

\section{Contribution}

Beach tourism is one of the most popular activities of travel. By awarding Blue Flag status to a beach, it is understood that the beach management might be following all the statutes laid down in Blue Flag programme. By complying with 29 criteria covering the aspects of water quality, environment education, information and management and safety and service issues, Blue Flag ensures a sustainable tourism development.

\section{Greenglobe}

Green Globe is one of the programmes of EC3 Global-an international environmental advisory group providing pathways to different organizations to attain sustainable targets (Green Globes, n.d). Green Globe Programme (Underpinned by Earthcheck Science) is supported by Sustainable Tourism Cooperative Research Center (STCRC), the world's largest dedicated, not for profit, research centre specializing in sustainable tourism. This web- 
delivered program established by the World Travel and Tourism Council (WTTC), is based on the Agenda 21 policies and provides a set of principles for local, state, national and international action on sustainable development and has resulted in Agenda 21 for the Travel and Tourism Industry: Towards Environmentally Sustainable Development, which lists an action plan for a number of overall objectives for the industry.

\section{Key Highlights}

Becoming a certified company or community with the Green Globe provides a framework to aid the organization's strategic and decision making processes and benchmark and certify their environmental and social performance. The programme assists companies to address the major environmental challenges that face our planet today which are, Reduction in greenhouse gas emissions; Energy efficiency, conservation and management; Reduction in the consumption of fresh water and resources; Ecosystem conservation and management; Support for local community development; Improved management of social and cultural issues; Improved land use planning and management; Improved air quality and noise reduction; Improved waste water management and Waste minimisation, reuse and recycling. The programme benefits the community by empowering local people and building on local initiatives. In short, it assists in developing a clear sustainable vision for a community.

\section{Contribution}

To promote sustainable tourism development, every aspect of tourism industry has to be examined and made efficient. Green Globe focuses on the entrepreneurial aspect by providing guidelines to travel and tourism businesses in going green thereby achieving sustainability (Keith, 2006). The certification by Green Globe ensures the protection of local and global environmental quality, production of less waste, improvement in profitability and attracting new consumers looking for products and services with better environmental profiles. The last two points helps in luring enterprises and thus promoting sustainability. 


\section{PAN Parks}

PAN Parks or Protected Area Network Parks are a network of protected wilderness areas in Europe. World Wildlife Fund (WWF), the conservation organization founded PAN Parks in partnership with the Dutch leisure company Molecaten in 1997.The years between 1997 and 2002 were primarily used to develop a long term strategy and to form a strong institutional base to help PAN Parks gain widespread international respect and support (PAN Parks, n.d). The year 2002 saw the first certified PAN Parks in Finland, Poland and Sweden, and the network is growing year after year.

\section{Key Highlights}

The programme aims to provide better long-term conservation and tourism management of those National Parks which were previously undervalued due to their location in remote and/or poorer areas of the continent. It also employs a comprehensive approach to meet the complex ecological and social needs of Europe's protected areas aiming to enhance the image and the recognition of Europe's diverse nature. Furthermore, it ensures the long-term survival of pristine nature while encouraging local communities to flourish.

\section{Contribution}

A very novel and creative concept, PAN Parks can provide an effective way of environment sustainability. The sustainable tourism development strategy is a cornerstone PAN Parks plan, ensuring that tourism supports nature conservation, and guaranteeing that tourism is not introduced in sensitive areas. Principles four and five of PAN Park programme set criteria for a sustainable tourism development strategy.

In general, all the three ecolabels are working toward sustainable development. Almost all the sectors of tourism industry are covered by these ecolabels. If all the tourism organizations become part of these ecolabels, total sustainable development can be achieved. 


\section{SWOT Analysis and Indian Case Scenario}

\section{Blue Flag}

\section{Strengths}

Blue Flag is a vast and successful organization with a vast reach covering 3200 beaches and marinas under its certification. The procedure of attaining the Blue Flag status is quite simple and absolutely feasible with no red tapism involved. Blue Flag beaches in any country are recognized as vital element in attracting tourists; therefore this ecolabel becomes a motivational force for beach tourism. This eco-label is internationally recognized and valued which indicates that its scope is not confined to local or national boundaries. In a nutshell, Blue flag, a sign of clean waters, pristine sand and a well-organized beach, promotes and demonstrates an ecologically sound world which makes it one of the most important organizations in sustainable development.

\section{Weakness}

There are only 37 countries involved so far which shows that there is lack of awareness in the rest of the world. There is Blue Flag International, but it coordinates and communicates mostly with National Blue Flag. Many of the countries which are full of beaches do not have any link with Blue Flag which indicates that physical presence through affiliated organizations is lacking. If a new country wants to start up the programme, the organization dealing with it should be a non-profit concern. This condition might work well with developed nations, but under developed economies might not be able to comply with it, as most of the population in these countries expects remuneration for any work done.

\section{Threats}

Natural calamities like floods can cause serious detrimental effects on water quality by increasing the amount of diffuse pollution into the sea. This in turn causes a loss of Blue Flag status to a beach, making it a grave threat to Blue Flag. One such example would be English beaches. Because of the continuous floods in 2007 and 2008, many English beaches have seen a fall in Blue Flag status in 2009. Similarly, with lack of necessary funds, many beaches have a threat 
of losing the status like some of the Irish beaches have already lost the certification.

In some cases, there is a threat of resistance from the local community. Mere flying of Blue Flag might evoke retaliation of ethnic groups indicating that they are better in managing their heritage than some foreign attestation.

\section{Opportunities}

Awareness has to be brought throughout the world by opening offices/ links in every nation. Media marketing through broadcast programmes and printing published material will help in advertising about the Blue Flag programme. Creating good public relations with the rest of the world in order to increase involvement of people globally is another way of promoting Blue Flag which will eventually lead to a sustainable beach environment. The opportunity of providing financial assistance to those who face scarcity of resources in implementing Blue Flag programme can help in covering more beaches. Lastly, education to local ethnic communities of the advantages of the Blue Flag status and ensuring their participation in the programme will help in reducing the resistance on behalf of locals.

\section{Indian Scenario}

Surrounded by water on three sides, the vast peninsular coastline of India offers an incredible display of beaches. Beaches of India extend almost $6,000 \mathrm{~km}$ long coastline which covers both west coast beaches and east coast beaches. The most notable beaches in India are almost 200 in number which includes beaches and marinas along the coastline of Isles of Andaman and Nicobar, and Lakshadweep (List of beaches in India, n.d). Beaches of India, since ages, have been reflecting the spectacular beauty of the countries coastlines displaying the myriad colours of the flashy fish in the coral reefs from above the waters but, unfortunately, do not have Blue Flag certifications. Though national laws and regional rules and regulations by governing bodies have been put in statutes, none are actually implemented in reality. There are loopholes in the system which results in bad management of the beaches. Nobody is held accountable even after assessment of beaches indicates bad water quality, depleting flora and fauna and deterioration of 
beaches. Many beach management projects are under direct control of local panchayats. In many cases, the court passes an order directing the coastal panchayats (Local Bodies) to collect, segregate and dispose the garbage by building composting units and also collect plastic waste for recycling, but piles of waste still get accumulated, e.g.: Goa beaches (Erring Coastal Panchayats, 2009) Thus, a stringent international law is the need of the hour. An international eco-label like Blue Flag certification must be made a requirement for opening up a beach to the public. It is a wellknown fact that unregulated tourism development, both regional and international, on beaches has been the major catalyst for a wide spectrum of detrimental environmental and social changes (Ghosh and Datta, 2012). Standing on the thin line between survival and destruction, the beaches, lagoons and marinas of India need more initiatives from all corners to protect themselves from the havocs created by the consumerist urban-industrial culture. In this context, several sustainable development oriented guidelines as put forward by eco label certifications, like Blue Flag, should be initiated to enhance the local resource pool, thereby saving beaches inter-generationally as well as intra-generationally.

\section{Green Globe}

\section{Strengths}

Green Globe has an international presence; the programme is being tailored for all companies, communities and consumers and is also feasible enough with a detailed framework provision for attaining sustainability. By providing guidelines to companies on how to reap benefits like reduction of costs, global recognition etc., the programme lures all travel and tourism concerns. Similarly, the strength of Green Globe lies in the fact that many communities have achieved socio-economic benefits by following the framework. The programme is not restricted to hotels only, a total of 25 different sectors of travel and tourism industry are also included.

\section{Weakness}

The overall cost of getting certification can be unaffordable for many organizations. In today's dynamic world, environment 
(political, economic, technological) changes fast, things become obsolete and therefore, to get a certification in two years might seem a long period for organizations.

\section{Opportunities}

The scope of programme can be widened by bringing awareness, educating, conducting training and workshops for all employers, employees, local communities and ethnic groups to work towards sustainability. An inclusion of small and medium scale travel and tourism enterprises should be done by reducing the cost of certification. Since the programme is brimming with expertise about sustainable tourism businesses, there is a potential for the organization to venture into the market itself. This will give demonstration to other concerns and will also generate more awareness.

\section{Threats}

There is a lot of competition from other regional and national certifications like IGBC (Indian Green Building Council), ECOTEL, LEED, BEE etc. Due to economic recession, all organizations are looking for ways to cut down costs and getting a certification will mean investing more capital. This type of investment might discourage organizations to apply for certification.

\section{Indian Scenario}

Indian economy has witnessed considerable progress in the past few decades. Most of the infrastructure development sectors are moving forward, which include construction of hotels and resorts to accommodate booming tourist flow. The construction industry alone has contributed a share of around Rs $670,788(8 \%)$ to the national GDP in the year 2011-12 (Construction Industry of India, n.d). Travel and Tourism sector, which includes hospitality industry too, contributed an estimated figure of Rs 368,039 (4.5\%) to the national GDP in the year 2011 (Hotel room supply, capital investment and manpower requirement by 2021, n.d).

In the past 15 years, the growth in the number of travellersin India, both domestic and international, has clearly been dominating factor to consider in this burgeoning economy. In India, the total number of travellers in the year 2011 was 810 million while the total 
number of hotel rooms which include internationally and domestically branded hotels, independent unbranded hotels and guest houses is around 120,000 to 140,000 (Hotel room supply, capital investment and manpower requirement by 2021, n.d). This imbalance shows a huge dearth of hotel accommodation for the tourists. The domestic traveller today has the propensity and, more importantly, the intent to spend. The hotel industry has, in recent years, woken up to recognize this segment's growth potential and we are now witnessing a host of branded products that vary across the spectrum of positioning entering the market. The Indian Hospitality Industry catching the pulse has particularly soared up in construction of infrastructure, specifically hotel accommodation. It is commendable that many of such constructions follow 'green' practices. Most of the time, sustainability is kept in mind while constructing the properties. A total of four such constructions in India have Green Globe certifications which are: Svaastha-the harmony spa in Coorg, Karnataka, Hotel United 21 in New Delhi, Club Mahindra, Lakeview Munnar, Kerala and Club Mahindra Fort Kumbhalgarh, Rajasthan. Though four properties in world's second most populous country seem negligible, there are other Green/Sustainable certifications used by Indian hotel industry like ECOTEL, IGBC, LEED and BEE. Then there are environmental laws governing the overall operation of hotels and resorts, which most us would agree, are hardly followed. A dysfunctional system, where laws are hardly implemented, makes it a mandatory to get international body to act. One such example would be Green Globe certification, which can ensure transparent system with a sustainable tourism development.

\section{PAN Parks}

\section{Strengths}

The core values of Cooperation, Integration, Networking, Innovation and Openness makes PAN a strong and dedicated organization. Since the organization is relatively new, there is less resistance to changes beneficial for the organization plus the programme is highly focused to wilderness areas, which gives the organization an edge to excel in this field. One of the principle focuses is on the restoration of biodiversity implying that there will 
not be any threat of extinction of a species. Local community is also involved in PAN parks group indicating that the implementation of strategies will be effective.

\section{Weakness}

The organization has its presence only in the European continent. This shows that not many are aware of the programme. Only 10 or 11 wilderness areas have been in PAN programme so far. A new organization may be viewed sceptically by many and might imply lack of trust in the programme and therefore, will not attract many stakeholders/volunteers.

\section{Opportunities}

Exploration outside of Europe where there could be a vast pool of wilderness areas in need of better management has to be considered. An awareness and education programme has to be launched in the entire world about the PAN parks through the media so that others can also apply for the verification or design similar programmes tailored to their needs. Promotion and Advertisements about already existing PAN Parks in order to increase tourist flow and also generating awareness among stakeholders should be considered.

\section{Threats}

This is comparatively a new concern and new organizations are prone to failures. Since it is a non-profit organization, raising funds under current turbulent economic times might be a concern and a constraint plus interferences from local activists makes it harder to conduct fundraisers. Competition from other well developed, more accessible national parks and sanctuaries poses another grave threat. Accessibility to some PAN Parks by car is not possible, hence ferries have to be used which is yet another drawback.

\section{Indian Scenario}

The concept of PAN parks applies only to European wilderness reserves. In India, the wilderness area that needs to be protected is given a status of national parks, animal sanctuaries, biosphere reserves, reserved and protected forests, village and panchayat forests, conservation and community reserves, conservation areas or private protected areas (Protected Areas of India, n.d), depending 
upon the requirements of conservation/preservation. India has more than 442 animal sanctuaries referred to as Wildlife sanctuaries. These sanctuaries come under IUCN (International Union for Conservation of Nature) Category IV protected area. IUCN is an international body which is dedicated to finding practical solutions for environment and development challenges, and publishing IUCN 'Red List of Threatened Species' (What is IUCN, n.d). The authorized number of National parks in India is 166, out of which 102 have already been established (List of National Parks of India, n.d), and these national parks belong to IUCN category II protected area. Similarly, India does have biosphere reserves which are UNESCO designated, and other forms of protected areas which are mentioned above in this paragraph, but the big question is, "Are these conservation efforts and plans really paying off?". Research and literature both reveal a highly failing and corrupt system, leading to aspersions on authorities. For example, in the year 2012 around 78 tigers were killed, mostly by poachers. This is the highest number in the past 12 years and on an average, every year, for past three to four years, around 50 tigers get killed for personal business gains (Sharma, 2012). Similarly, Karera wildlife sanctuary in Madhya Pradesh has been another such case. Once known for the endangered Great Indian Bustard's habitat, the sanctuary today has not a single bird species, largely due to apathy and mismanagement of the bureaucracy (Karera wildlife sanctuary on its deathbed, 2008). The sanctuary is in the process of being denotified due to the opposition by local people (Karera Wildlife Sanctuary, n.d). However, there are some success stories too in some conservation projects. But most of these cases are initiatives by private NGOs and some undertaken by international organisations like WWF and UNESCO. Some of these initiatives include Saving Asia's Vultures form Extinction (SAVE) by establishment of vulture safe zones, Ecosystems for Life: A Bangladesh-India Initiative to promote better understanding of trans-boundary ecosystems in Bangladesh and Indiathrough collaborative research and studies, cleaning up of lakes through Rolex awards and the like (IUCN in India, 2013).

Be it PAN park certification, IUCN categorisation, Sanctuaries or National park status, what India needs is stringent laws and their 
strict implementation. Raising their preservation efforts to the international standards is also mandatory, plus a reprimand for those who break the laws, a must action.

\section{Evaluation of Eco-Label Implementation vis-a-vis Sustainability Dimensions}

India's concern for sustainable development is gaining importance rapidly and the entire universe seems to be aware of the concept while doing very little to keep it thriving. According to McIntosh, Goeldner and Ritchie (1995), "The concept of sustainable development has achieved prominence and acceptance in recent years and hopefully, it will permeate all levels of economic development and tourism development, from local to global in the future." A very profound and unique way of achieving sustainable tourism development is Eco-Labelling. Ecolabels are labelling systems for consumer products, often voluntary in implementation. They are a form of sustainability measurement directed at consumers or stakeholders, intended to make it easy to take environmental concerns into account thereby quantifying pollution or energy consumption by way of index scores or units of measurement. Others simply assert compliance with a set of practices or minimum requirements for sustainability or reduction of harm to the environment. If almost everybody is aware of sustainable tourism development and role of ecolabels in attaining it, does that imply that all tourism destinations get Eco-label certifications and hence are sustainable? To get some perspectives about whether or not destination India follows Ecolabelling criteria and sustainable practices, an evaluation seems imperative.

In order to evaluate sustainability of Indian Tourism Industry, two frameworks will be used against three international ecolabels which are: Blue Flag, Green Globe and PAN Parks. The first framework is a simplified description of the sustainable development spectrum, on which different sustainability positions and their defining characteristics have been briefly explained (Harris, Griffin \& Williams 2002). The second framework is called Prism of sustainability (Adapted from: Spangenberg \& Valentine, 1999), which is given by Berg, Bree \& Cottrell (2004), evaluates case studies using four dimensions important in sustainable 
development which are: Institutional, environmental, social and economic both the frameworks will be used simultaneously. A matrix (grid) will be formed (Table 1). One side of the grid (Horizontal axis) will show the three Eco-labels and the other side of the grid (Vertical axis) will display the four dimensions of prism of sustainability. The cells of the grid will have sustainable positions ranging from very weak to very strong depending upon the evaluation done by the researcher. Hence, each cell will give us a position as to where a particular variable (Institutional, Social, economic or environmental) of our case study stands against sustainable positions in regards with the Eco- labels.

Table 1. Eco Labels

\begin{tabular}{|l|l|l|l|}
\hline & \multicolumn{1}{|c|}{ Blue Flag } & Green Globe & PAN Parks \\
\hline Institutional & Very weak & Weak & Very Weak \\
\hline Social & Weak & Very Weak & Very Weak \\
\hline Environmental & Very Weak & Very Weak & Strong \\
\hline Economic & Strong & Strong & Weak \\
\hline
\end{tabular}

Sustainability Positions Used: Very Strong, Strong, Weak, Very Weak.

\section{Findings from the Grid}

The matrix indicates that destination India ranks very low on the sustainability and ecolabelling chart. The evaluation indicates that the destination is following practices which are deemed as being non- sustainable. To explain each position of the dimensions on sustainability spectrum, let us look at each ecolabel separately.

\section{Blue Flag}

Institutional Dimension: As explained in the above paragraphs, there are a lot of issues and concerns related to the laws being implemented on Indian beaches and marinas. The rules and regulations are not followed, be it about waste disposal by panchayats (Local governing bodies) or dumping garbage in rivers by casinos, hotels, or local population. According to a website, "Offshore casinos and hotels in many states do not conform to the definition of the term 'offshore' accepted by the global shipping community, which is 12 nautical miles from the shore" (Goa's offshore casinos, 2009). There are rules for every single change in the 
beach ecosystem, but unfortunately, none are being followed and absolutely nobody is held accountable if discrepancies are found. Hence, this dimension attains a 'very weak' status on the sustainability spectrum.

Social Dimension: The society in general and indigenous population in particular of most of the beaches in India do not seem to have much of social degradation issues due to missing international certification to the beaches of their state. However, an indirect impact of mismanagement of beach can be felt in local population through an imbalance in aquatic biotic and abiotic ecosystems. These include and are not limited to health concerns, crop failures and pollution. Therefore, a status of 'weak' sustainability position on the spectrum justifies the social dimension of Blue Flag on Indian beaches.

Environmental Dimension: This dimension for sure, gets the 'very weak' status on the position scale of sustainability. There is ample literature on beaches depicting their grave conditions related to the environment. Internet is flooded with the websites showing the deteriorating conditions of beaches. Beach tourism without certifications and ecolabels has changed the land use pattern to a large extent. Land available anywhere is immediately used for construction of commercial establishments and as dumping grounds, violating CRZ (coastal regulation zone) guidelines (Case study of Zero Waste Kovalam, 2005). These objects, when exposed in monsoon, create environmental nuisance. Illegal sand mining, construction of concrete structures in the name of beautification of beaches and huge tourist pressure beyond the ecosystem's carrying capacity in peak seasons also contribute to the vulnerability of this fragile coastal ecosystem (Radhakrishnan, 2004). Despite the efforts made by NGOs and volunteer bodies, the condition of Indian beaches remains wretched.

Economic Dimension: Half of the income in many famous beaches of India is generated through tourism. Infrastructure development is a product of economic boom in such places. Local population receives most of the gains and most of the income generated circulates inside the state (Wilson, 1997). The beaches, though not certified, reap many financial benefits for the local living 
population. This criterion puts economic dimension of India viz-aviz Blue Flag at a 'strong' position.

\section{Green Globe}

Institutional Dimension: IGBC (Indian Green Building Council) has licensed the LEED Green Building Standard from the U.S. Green Building Council currently, is responsible for certifying LEED-New Construction and LEED-Core and Shell buildings in India. There are many energy efficient buildings in India, situated in a variety of climatic zones. One of these is RMZ Millenia Park, Chennai, India's largest LEED gold-rated Core and Shell green building (Green Building in India, n.d). Similarly, there are laws by Bureau of Energy Efficiency (BEE) and their guidelines through ECBC (Energy Conservation Building Code) which apply to many construction sites in India. Again, laws are made but hardly followed. They are rather broken without any reprimand. Moreover, India has only 267 green buildings, which is very less in a country with a population of 1.24 billion. Therefore, on this criterion, the green globe certification in India gets a 'weak' sustainable position.

Social Dimension: Society as a whole faces the direct brunt of its institutional frame work when it comes to growing economies like India. One of the main problems India faces is an extreme dearth of energy resources. Inefficient energy saving system leads to waste of resources which directly seeps into lower social classes. This type of degradation is quite rampant in India. Certifications like Green Globe and Green Building ensure 5 key areas which are: sustainable development, water conservation, energy efficiency, material selection and indoor environment quality (Green building in India, n.d), which in turn help economies in uplifting all social strata, be it their health care, basic necessities or education. Since most of these basic requirements in majority of the Indian population are missing, therefore, the sustainable spectrum shows a 'very weak' stand on this point.

Economic Dimension: Despite unsustainable construction with very little concern for the environment, India is one of world's fastest growing economies. Indian economy is the world's tenth largest in terms of nominal GDP and the fourth largest in terms of purchasing power parity (20 astonishing facts about the Indian 
economy, 2012). According to the International Monetary Fund, India's nominal GDP stands at $\$ 1.53$ trillion. In terms of purchasing power parity, India's economy is the fourth largest in the world at $\$ 4.06$ trillion. India could emerge as the world's third largest economy by 2030, benefiting from strong domestic demand and favourable demographics, according to a Standard Chartered Global research study. Since, the economy is burgeoning, hence the status 'strong' on the spectrum.

Environmental Dimension: Like social dimension, this dimension is also a direction function of institutional dimension. A 'weak' institutional background leads to a 'very weak' environmental structure. A total of just 4 buildings with green globe certification and only 267 green buildings in world's fastest growing economies, says it all.

\section{PAN Parks}

Institutional Dimension: As already mentioned, PAN parks is a European Wilderness conservation project. The equivalent of this project in India is National parks, Sanctuaries, biosphere reserves etc. The position of this dimension on sustainability spectrum is 'very weak'. The reason being lagging law and order, security issues related to flora and fauna of the protected areas, illegal trade of animal and plants which are supposed to be protected and preserved, and very little to no concern on behalf of the authorities.

Social Dimension: A very small number in the local population is included in protected area projects. And in majority of the cases there is a conflict with the local people related to such projects. Concept of local living economy is hardly followed which results in resentment and thereby leading to illegal ways of financial gains. To name a few, the challenges for wildlife protection in such cases are - encroachments into parks by neighbouring villages, cattle grazing, poaching, retaliatory killings, the demand for animal skins and parts, frequent man-animal conflicts and a shrinking forest cover (Singh, n.d). Since, authorities are doing very litte to combat the hindrances, therefore this dimensions takes on 'very weak' sustainable position. 
Environmental Dimension: Though laws may not be strictly followed, this dimension does take on a position of 'strong' on sustainability spectrum, the reason being the work of national and international NGOs, volunteer groups, and some non-profit concerns by a few giant business groups. Government of India also has gained some success in certain national parks and wildlife sanctuaries. Project Tiger is one such initiative. Others include projects by non-government bodies like vulture safe zones (VSZs), conservation of wild buffalo in central India, sustainable hilsa fisheries management and many more (IUCN in India, 2013). There are also conferences, conventions, seminars and summits held which promote safe environment for India's biodiversity.

Economic Dimension: There are monetary benefits but in an illegal way, like poachers getting into illegal trade, which actually leads to economic leakage of national treasure by loss of natural resources. There are examples where in these protected areas have failed leading to loss of invested money and resources. However, there are some successful cases too. In Khichan, a village co-operative collectively funds the feeding of large flocks of Demoiselle Cranes each winter. In a $7 \mathrm{sq}$. $\mathrm{km}$ tract of shallow land called Tal Chhapar, locals protect and feed thousands of blackbucks, a Schedule-A animal as per the Indian Wildlife Act (Singh, n.d). Similar protective efforts are on at several parks across India. So, instead of a 'very weak' stand, this dimension gets a 'weak' status on sustainability spectrum.

\section{Significant Suggestions}

After an analytical evaluation of the case study of destination India, it can be concluded that sustainability of tourism industry is at a very early and fragile stage. Though the concept of sustainability in India is not new but everybody, such as the locals, law makers, authorities, non-residents and even the stakeholders seem to ignore it. It is a fact that 100 per cent perfection in the system is not possible and total sustainability cannot be achieved, but setting up small goals will lead to long term solutions. The need of the hour is focused small baby steps by going 'green' like following the basics, not littering the place, not disposing garbage into fresh and clean 
water bodies, recycling, getting certified by 'green' organizations, following successful models, abiding by laws, etc. All these things have to start at a unit level which can be an individual, a small marina, a small restaurant or a wild area. Being proactive and not just reactive will lead to strategic solutions related to sustainable tourism development. Starting with one unit, a whole community and ultimately the whole of India can be involved. And this has been proved by many success stories of some pioneer organizations where in significant difference have been made. While ecolabels can 'propagate' sustainable tourism development, authorities can 'ensure' sustainable tourism development. This evaluation brought to light various discrepancies on behalf of the authorities at local, regional and national levels. From security and safety issues to both flora and fauna, environmental deterioration, health hazards and social evils like poaching, smuggling to economic downturn, cultural degradation and infrastructural problems, all can be dealt with if authorities play an active role in making ecolabels mandatory and its implementation a must. Active action, certification and participation on behalf of both stakeholders and authorities in all sectors of tourism industry are of the utmost importance. Ensuring following of proper rules, regulations and laws will promote proper order in the country and hence the good will.

In a nutshell, an integrated approach to sustainability, which involves ecolabel certifications by businesses and other stakeholders, their proper implementation and a follow up by the authorities has to be launched through awareness and education programmes. At an individual level, each one of us has to develop a conscious behaviour which works towards a sustainable world, as McIntosh et al (1995) puts it, "If it (sustainability) is to work, sustainable development must become a normal way of thinking and acting by a majority of the global community. It cannot be the exclusive purview of the enlightened segments of a society or of an industry." 


\section{References}

Aldred, J. (2009). Drop in England's 'blue flag' beaches. Retrieved from.http:// www.guardian.co.uk/environment/2009/may/07/blueflag-beaches-england

Blue Flag Beach. (n.d.). Retrieved May 4, 2013 from Wikipedia, the free encyclopedia: http://en.wikipedia.org/wiki/Blue_Flag_beach

Blue flag. (n.d.). Retrieved from http://www.blueflag.org/ Menu/ Publications

Berg, C. V. D., Bree, . F. V., \& Cottrell, S. (n.d.). Pan parks implementation process: cross cultural comparison - bieszczady and slovenski raij national parks. Retrieved from http://www.metla.fi/julkaisut/ workingpapers/2004/mwp002-32.pdf

Case study of Zero Waste Kovalam, (2005). A progressive waste management programme with a focus on the best available technology options and material substitution. Thanal, India.

Construction industry of India. (n.d.). Retrieved April 10, 2013 from Wikipedia, the free encyclopedia: http://en.wikipedia.org/wiki/ Construction_industry_of_India

Ecolabel. (n.d.). Retrieved March 4, 2013 from Wikipedia, the free encyclopedia: https://en.wikipedia.org/wiki/Ecolabel

Ecolabel index. (n.d.). Retrieved April 23, 2013 from: http://www.ecolabelindex.com/

Erring coastal panchayats to deposit Rs 25,000. The Times of India. Retrieved from http://articles.timesofindia.indiatimes.com/2009-0624/goa/28183809_1_panchayats-plastic-waste-garbage-disposal

Green Globes. (n.d.). Retrieved February 2, 2013 from Wikipedia, the free encyclopedia: http://en.wikipedia.org/wiki/Green_Globes

Green building in India. (n.d.). Retrieved March 14,2013 from Wikipedia, the free encyclopedia: http://en.wikipedia.org/wiki/ Green_building_in_India

Global ecolabeling network. (n.d.). Retrieved April 04, 2013 from: http://www.globalecolabelling.net/what_is_ecolabelling/index.htm

Goa's offshore casinos should be 12 nautical miles from shore: Expert. (2009, June 03). Thaindian News. Retrieved from http:// www.thaindian.com/newsportal/business/goas-offshore-casinosshould-be-12-nautical-miles-from-shore-expert_100163522.html 
Ghosh, P. K., \& Datta, D. (2012). coastal tourism and beach sustainability: An assessment of community perceptions in Kovalam, India . Malaysia Journal of society and Space, 8(7), 75-87

Harris, R., Griffin, T., \& Williams, P. (2002). Aspects of the sustainable tourism debate from a natural resources perspective, sustainable tourism: A global perspective. MA, USA: Butterworth- Heinemann.

Hotel room supply, capital investment and manpower requirement by 2021. (n.d.). Retrieved May 12,2013 from: http://www.hospitalitynet.org/ file/152004858.pdf

Introduction to eco-labels and standards. (n.d.). Retrieved May 20, 2013 from http:/ / epa.gov/greenerproducts/standards/

IUCN in India. (2013). Retrieved from http://www.iucn.org/about/ union/secretariat/offices/asia/asia_where_work/india_programme_ office/

Jayaraman, N. (2005). Case study of zero waste Kovalam: A progressive waste management programme with a focus on the best available technology options and material substitution. International POPS Elimination Project, Thanal: Thiruvananthapuram.

Karera Wildlife Sanctuary. (n. d.). Retrieved April 04, 2013 from Wikipedia, the free encyclopedia: http://en.wikipedia.org/wiki/ Karera_Wildlife_Sanctuary

Karera wildlife sanctuary on its deathbed. The Times of India. Retrieved from http://articles.timesofindia.indiatimes.com/2008-10-07/florafauna/27916096_1_black-bucks-great-indian-bustard-sanctuary-inmadhya-pradesh

Keith, R (2006, 09 10). [Web log message]. Retrieved from http:/ / www.temasactuales.com/temasblog/environmentalprotection/ eco-certification-for-tourism-the-role-of-green-globe-parti)

List of national parks of India. (n.d.). Retrieved March 03, 2013 from Wikipedia, the free encyclopedia: http://en.wikipedia.org/wiki/ List_of_national_parks_of_India

List of beaches in India. (n.d.). Retrieved May 10, 2013 from Wikipedia, the free encyclopedia: http://en.wikipedia.org/wiki/List_of_ beaches_in_India

McIntosh, R. W., Goeldner, C. R., \& Ritchie, J. R. B. (1995). Tourism and environment, tourism: Principles, practices and philosophies. NY,USA: John Wiley \& Sons.

PAN Parks. (n.d.). Retrieved October 4, 2012 from Wikipedia, the free encyclopedia: http://en.wikipedia.org/wiki/PAN_Parks 
Protected areas of India. (n.d.). Retrieved March 20, 2012 from Wikipedia, the free encyclopedia: http://en.wikipedia.org/wiki/Protected_ areas_of_India

Radhakrishnan, S. (2004, 04 16). Zero waste centre to go on stream from June. The Hindu Thiruvananthapuram Edition

Singh, A. (n.d.). Indian wildlife overview. Retrieved from http:// www.wildworldindia.com/parks/index.asp

Sharma, P. (2012, 12 09). Tiger trauma for India: Despite stringent laws, number of poaching deaths hit all-time high read more at. India Today. Retrieved from http://indiatoday.intoday.in/story/tigers-poachinggovernment-says-that-despite-laws-number-of-poaching-deaths-hashit-all-time-high/1/236859.html

Wilson, D. (1997). Paradoxes of Tourism in Goa [Abstract]. Annals of Tourism Research, 24(1), 52 - 75.

[Web log message]. Retrieved from http://www.guardian.co.uk/ sustainable-business/blog

What is IUCN (n.d) International Union of Conservation of Nature Retrieved from http://www.iucn.org/about/20 astonishing facts about the Indian economy (2012, 06 13). [Web log comment]. Retrieved from http://www.rediff.com/business/slide-show/slideshow-1-heres-why-you-can-cheer-indias-success/20110613.htm/ 